NBSIR 81-2246

\title{
Biodeterioration of Standard Reference Materials
}

G. J. Olson, W. P. Iverson, and F. E. Brinckman

Chemical Stability and Corrosion Division

Center for Materials Science

U.S. Department of Commerce

National Bureau of Standards

Washington, DC 20234

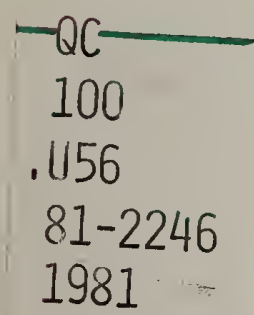

Prepared for

Office of Standard Reference Materials National Bureau of Standards

Washington, DC 20234 

..

\section{BIODETERIORATION OF STANDARD REFERENCE MATERIALS}

G. J. Olson, W. P. Iverson, and F. E. Brinckman

Chemical Stability and Corrosion Division

Center for Materials Science

U.S. Department of Commerce

National Bureau of Standards

Washington, DC 20234

April 1981

DISTRIBUTION OF THIS DOCUMENT IS UNLIMITED

Prepared for

Office of Standard Reference Materials

National Bureau of Standards

Washington, DC 20234

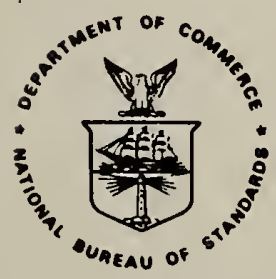

U.S. DEPARTMENT OF COMMERCE, Malcolm Baldrige, Secretary NATIONAL BUREAU OF STANDARDS. Ernest Ambler, Director 

CONTENTS

Page

List of figures................. . . iv

List of Tables ................ . . v

1. Introduction ................ 1

2. Experimental Procedures ............. 4

2.1 Enumeration of Microorganisms ........ 4

2.2 Elemental Analysis ............ . . 4

2.3 Exposure and Storage of SRMs ......... 5

2.4 Mercury Binding . . . . . . . . . . . 5

2.5 Chromium ................ 5

3. Results and Discussion............. 5

4. Conclusions and Recommendations ........... 9

5. References................. 11 


\section{LIST OF FIGURES}

Page

1 Dual tube growth/absorbing system for measurement of volatile microbial metabolites . . . . . . . . . . . . . 4

2 Freeze dried urine rehydrated with sterile and non-sterile distilled water 


\section{LIST OF TABLES}

Page

1. Elements, transformations, and SRMs ......... 3

2. Numbers of microorganisms in urban particulate ...... 5

3. Numbers of microorganisms in freeze dried urine . . . . 6

4. Binding of mercury to cells in urine ......... 7

5. Growth of microorganisms on SRMs exposed to outdoor air then stored at varying relative humidity ........8 8 

Biodeterioration of Standard Reference Materials

G. J. 01son ${ }^{1}$, W. P. Iverson, and F. E. Brinckman

Chemical Stability and Corrosion Division

Center for Materials Science

National Bureau of Standards

Washington, DC 20234

Several National Bureau of Standards Standard Reference Materials have been examined for susceptibility to biodeterioration. Several of these materials were attacked by bacteria and fungi when stored at elevated humidity after exposure to outdoor air. Some SRMs underwent deterioration after following certificate instructions for handling. Suggestions for some certificate revisions are made.

Key words: bacteria; biodeterioration; biotransformations; deterioration of materials; element volatilization; fungi; metals; microorganisms; Standard Reference Materials.

\section{Introduction}

The validity and reliability of Standard Reference Materials certified for elemental composition in a given host matrix require that homogeneity of the SRM, and the concentrations of the certified elements, will remain unaltered over a reasonable shelf life. This demands that no chemical or biological process will occur that alters the homogeneity or certified concentration of the specified elements or that alters the matrix so as to reduce homogeneity or change concentrations of those elements.

Many chemical or physical processes may occur during storage or use of SRMs which can result in composition changes. These include thermal cycling, photolysis, adsorption, volatilization, contamination, atmospheric oxidation, hydrolysis, and the like. Such occurrences have been studied in certain SRMs ( $R$. Alvarez, personal communication). A more subtle form of deterioration, which has not received adequate attention by analysts, may result from contamination by microbiota such as bacteria or fungi. Such biodeterioration may be initiated by microbiota originally present in the particular matrix employed, as with biological or environmental reference materials. Alternatively, contamination may be introduced subsequent to certification and sale to the

1979-81 NRC-NBS Postdoctoral Research Associate 
user, who may introduce microbiological contamination in following inadequate instructions for use or by using conventional handling procedures without adequate sterile controls.

Perhaps the most critical factor in the metabolism of the microbial cells present in contaminated SRMs is water availability. The most useful measurement of water availability is "water activity" $\left(a_{w}\right)$, defined as the ratio of the equilibrium vapor pressure of water over the material in question to that of pure water at the same temperature [1]. Growth of most microorganisms occurs only when $a_{w}>0.90$, however, xerophiles, (usually yeasts and molds) which grow under relatively dry conditions ( $a_{w}=0.85$ to 0.60 ), exist [1]. Microorganisms do not grow at $a_{w}<0.60$. Most biologically susceptible SRMs are freeze dried, and therefore, unless rehydration occurs, either accidentally or by design, they should not experience biological deterioration. Rehydration is possible, however, during customer use while dispensing and weighing or as a result of failure to close a bottle cap tightly. Condensation of moisture on a refrigerated SRM is very possible when it is moved to a warm laboratory.

Microbial or fungal attack on substrates containing trace $\left(10^{-6}\right.$ to $10^{-9} \mathrm{~g} \cdot \mathrm{g}^{-1}$ ) quantities of a particular element in a natural or introduced (spiked) form may well result in measurable losses or translocations of the element over relatively short periods of time. Much of the current environmental literature devotes considerable attention, for example, to the biological transformations, transport, and reaccumulation in new reservoirs (often biological) of many trace toxic elements, especially those frequently certified in needed SRMs $[2,3]$. Fortunately, modern measurement techniques and methods are available which are uniquely suited to assess the formation of certain molecular species containing elements of concern even if this occurs slowly and at very low concentrations. Such methods permit diagnostic use of such element-containing metabolites as kinetic markers for use in establishing degradation rates and predicting form and trends of deterioration of suspected SRMs. Table 1 lists some examples of microbially catalyzed transformations of certain elements certified in some of the SRMs potentially susceptible to biodeterioration. Volatile products are emphasized since these could lead to greatest loss of certified trace elements from SRMs.

The present paper reports preliminary work designed to survey a group of currently produced NBS SRMs which we regard as susceptable to biodeterioration, and for which certain elements, which we know to be especially susceptible to such biotransformations $[2,3]$, have been certified. 
Table 1. Examples of microbial transformations (especially volatile products) of elements and some SRMs certified for these elements potentially susceptible to such biodeterioration. Volatile species formed may be lost to the atmosphere resulting in alteration of certified element composition.

\begin{tabular}{|c|c|c|c|}
\hline Element & $\begin{array}{l}\text { SRM Certified } \\
\text { for Element }\end{array}$ & $\begin{array}{l}\text { Microbial Transfor- } \\
\text { mations of Element }\end{array}$ & $\begin{array}{l}\text { Typical Environments } \\
\text { Where Transformation } \\
\text { Occurs }\end{array}$ \\
\hline As & 1571,1648 & $\begin{array}{l}\left(\mathrm{CH}_{3}\right)_{3} \mathrm{As}, \mathrm{AsH}_{3}, \\
\left(\mathrm{CH}_{3}\right)_{2} \mathrm{AsH} \text { as gases; } \\
\mathrm{AsO}_{2} \text { in solution or } \\
\text { solid }\end{array}$ & $\begin{array}{l}\text { seawater }[4] \text {, } \\
\text { sewage }[5] \text {, } \\
\text { sediments }[6,7]\end{array}$ \\
\hline $\mathrm{Hg}$ & 2672,1645 & $\begin{array}{l}\mathrm{Hg}^{\circ},\left(\mathrm{CH}_{3}\right){ }_{2} \mathrm{Hg} \text { as } \\
\text { gases; } \mathrm{CH}_{3} \mathrm{Hg}^{+} \text {in } \\
\text { solution or solids }\end{array}$ & $\begin{array}{l}\text { tissue and urine }[8] \text {, } \\
\text { sediments }[9-12] \text {, } \\
\text { feces }[13] \text {, } \\
\text { water }[14,15]\end{array}$ \\
\hline $\mathrm{Cr}$ & $\begin{array}{l}1569,1570 \\
1571\end{array}$ & $\mathrm{Cr}^{+++}$in solution & $\begin{array}{l}\text { waters and sedi- } \\
\text { ments }[16,17]\end{array}$ \\
\hline$S$ & 1621 & $\begin{array}{l}\mathrm{H}_{2} \mathrm{~S},\left(\mathrm{CH}_{3}\right)_{2} \mathrm{~S}, \mathrm{CH}_{3} \mathrm{SH}, \\
\mathrm{CS}_{2},\left(\mathrm{CH}_{3}\right)_{2} \mathrm{~S}_{2} \text { as } \\
\text { gases }\end{array}$ & $\begin{array}{l}\text { soils }[18] \text {, } \\
\text { manure }[19] \text {, } \\
\text { waters and sediments } \\
{[20,21]}\end{array}$ \\
\hline $\mathrm{Se}$ & 1567 & $\begin{array}{l}\left(\mathrm{CH}_{3}\right)_{2} \mathrm{Se},\left(\mathrm{CH}_{3}\right)_{2} \mathrm{Se}_{2}, \\
\left(\mathrm{CH}_{3}\right)_{2} \mathrm{Se}_{2}, \mathrm{Se}^{\circ}(\mathrm{all} \\
\text { volatile) }\end{array}$ & $\begin{array}{l}\text { soils and sewage [22], } \\
\text { waters [23] }\end{array}$ \\
\hline $\mathrm{Pb}$ & 1571 & $\begin{array}{l}\left(\mathrm{CH}_{3}\right)_{4} \mathrm{~Pb} \text { (volatile), } \\
\text { organoleads }\end{array}$ & $\begin{array}{l}\text { bogs [24], } \\
\text { sediments [25] }\end{array}$ \\
\hline Sn & $2672^{*}$ & $\begin{array}{l}\left(\mathrm{CH}_{3}\right)_{2} \mathrm{SnH}_{2},\left(\mathrm{CH}_{3}\right)_{4} \mathrm{Sn}, \\
\text { other methyltin com- } \\
\text { pounds (most are } \\
\text { volatile) }\end{array}$ & $\begin{array}{l}\text { waters and sediments } \\
{[26,27,28]}\end{array}$ \\
\hline
\end{tabular}

ॠCertified for total $\mathrm{Hg}$ not Sn. 


\section{Experimental Procedures}

\subsection{Enumeration of Microorganisms}

Microorganisms in SRMs were enumerated by surface or pour plating [29] using trypticase soy agar or a modified iron-peptone agar [30] with glucose $\left(0.5 \mathrm{~g} \mathrm{~L}^{-1}\right)$ substituted for gluconate. Incubation was at room temperature (about $22^{\circ} \mathrm{C}$ ) or $37^{\circ} \mathrm{C}$.

\subsection{Elemental Analysis}

Mercury in urine was quantified using a manual cold vapor procedure [31] employing a flameless atomic absorption spectrophotometer (Mercometer, Anti-Pollution Control Technology Corporation). Volatile mercury was detected and identified using a tandem gas chromatographatomic absorption system [32]. Chromium was determined using a PerkinElmer model 360 atomic absorption spectrophotometer equipped with a graphite furnace. Chromium volatilization experiments were performed using a dual tube absorption system [33] shown in figure 1.



Figure 1. Dual growth tube/absorbing system for measurement of microbial metabolites. One tube contains sterile, deionized water, the other contains brewers yeast (SRM 1569) and contaminating fungal spores. Volatile metal-containing metabolites can be measured by atomic absorption after partitioning into the sterile water. 


\subsection{Exposure and Storage of SRMS}

Some of the SRMs were exposed to outdoor air (NBS grounds) for periods of 30 to 60 min on successive days (total exposure $3.5 \mathrm{hr}$ ), then were stored loosely capped at relative humidities of $100,90,70$, and 49 percent. The higher humidities were maintained using dessicator jars containing calcium chloride solutions [34], and the lowest humidity represented the laboratory ambient relative humidity which averaged 49 percent and ranged from 33 to 73 percent (April to June, 1980).

\section{4 Mercury Binding}

Mercury absorbed to cells growing in urine certified for mercury (low level, SRM 2672) was quantified by passing $5.0 \mathrm{~mL}$ of contaminated urine through a $25 \mathrm{~mm}, 0.45 \mu \mathrm{m}$ membrane filter (Millipore Corp.) to trap cells. After a $5.0 \mathrm{~mL}$ deionized water rinse, filters were digested in $1.5 \mathrm{~mL}$ plastic centrifuge tubes with $0.2 \mathrm{~mL} \mathrm{HNO}_{3}$ at $80{ }^{\circ} \mathrm{C}$ for $30 \mathrm{~min}$ to solubilize $\mathrm{Hg}$. The volume was made to $1.0 \mathrm{~mL}$ with deionized water and an aliquot of the digest was analyzed for total mercury [31]. Dry weights of cell material were determined by filtration through $0.45 \mu \mathrm{m}$ filters, rinsing as before, followed by drying to constant weight at $105^{\circ} \mathrm{C}$. Duplicate bottles were run in these experiments, and duplicate mercury determinations from each bottle were performed. Duplicate bottles rehydrated with sterile water and analyzed as above served as controls.

\subsection{Chromium Studies}

Possible chromium volatilization from brewers yeast and orchard leaves (SRMs 1569 and 1571), both certified for chromium, was investigated using a dual tube apparatus (fig. 1). The two SRMs were placed in a 100 percent relative humidity chamber for three days, then $3 \mathrm{~g}$ portions were added to $12 \times 100 \mathrm{~mm}$ glass screw cap tubes which were connected to an identical tube (containing $3.0 \mathrm{~mL}$ deionized water) via a thin glass tube through the caps. The SRMs were inoculated with fungal spores taken from contaminated brewers yeast and orchard leaves stored at high humidity. Aliquots of the deionized water were analyzed at intervals for total chromium using atomic absorption spectrophotometry.

\section{Results and Discussion}

A11 SRMs were found to be sterile as received except for the urban particulate SRM 1648 which contained more than $10^{4}$ viable microorganisms per gram (table 2). As a comparison, total counts of bacteria in soil range from $10^{5}$ per gram in poor soil to $10^{8}$ per gram in rich soil [35]. Freeze dried urine (SRMs 2671 and 2672) was sterile in the dehydrated form. Rehydration, however, with non-sterile water (though it may meet the purity requirement of $<0.1 \mu \mathrm{g} \mathrm{L} \mathrm{L}^{-1} \mathrm{Hg}$ set forth in the certificate) resulted in microbial contamination of the material (fig. 2). NBS 
Table 2. Numbers of viable microorganisms in several as received, urban particulate (SRM 1648) vials. Numbers indicate organisms per $\mathrm{g}$.

$$
\begin{array}{rr}
\text { vial } 1 & 4.00 \times 10^{4} \\
2 & 3.45 \times 10^{4} \\
3 & 3.20 \times 10^{4} \\
4 & 2.05 \times 10^{4}
\end{array}
$$

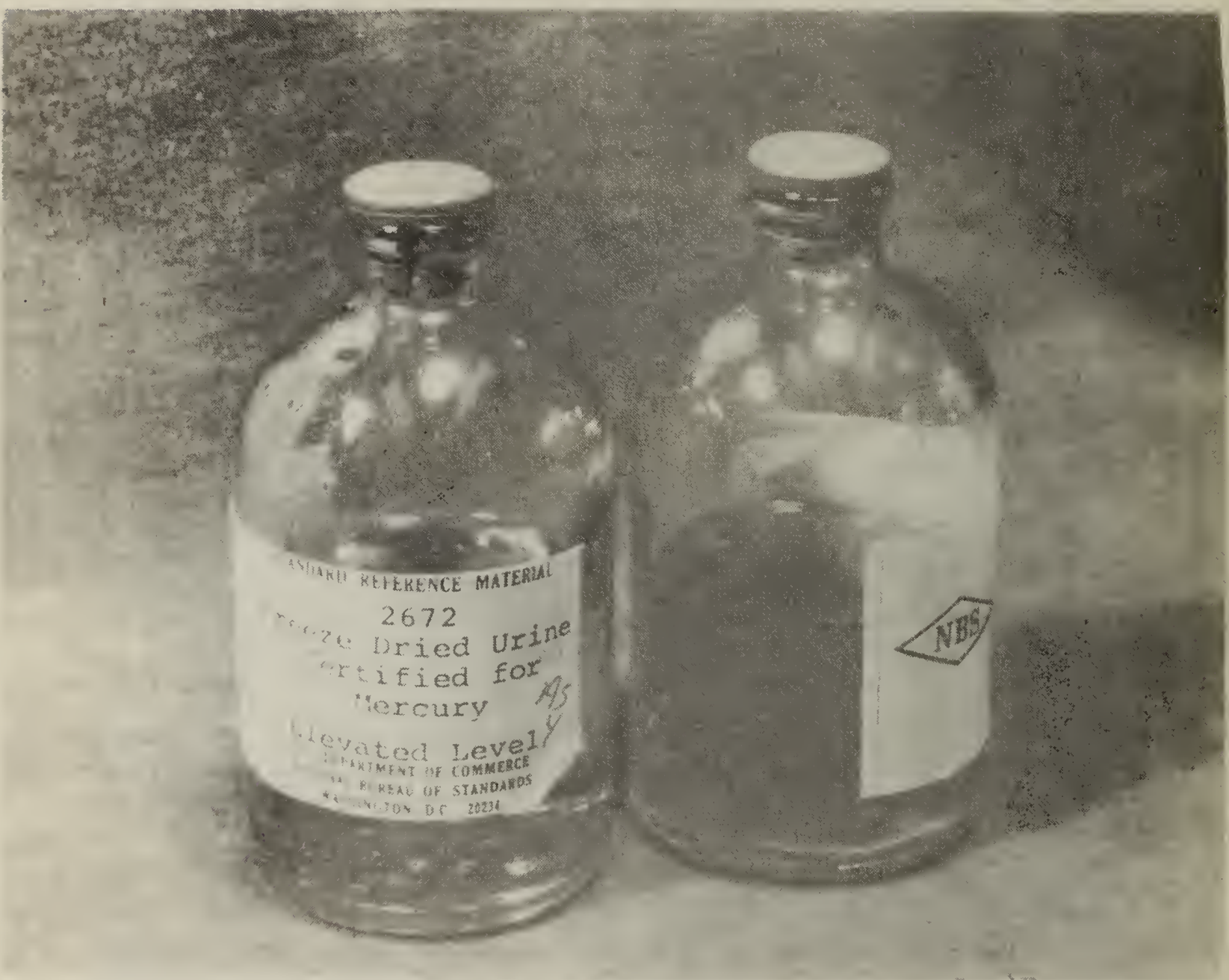

Figure 2. Freeze dried urine rehydrated with sterile (left) and nonsterile (right) distilled water. 
house distilled water used in the reconstitution of the urine did not contain detectable mercury $\left(<0.1 \mathrm{\mu g} \mathrm{L}^{-1}\right.$ by cold vapor atomic absorption, see reference 31 ), but contained more than 500 viable microorganisms per $\mathrm{mL}$. A sample of distilled water from a microbiology laboratory at the University of Maryland contained 1600 viable microorganisms per $\mathrm{mL}$. At $1{ }^{\circ} \mathrm{C}$ the cells do not grow in the urine, however if stored at room temperature these cells utilized nutrients in the urine and grew well, numbering greater than $10^{8}$ cells per $\mathrm{mL}$ in a few days (table 3 ). Consequently, depending on the number and kinds of microorganisms in the water used to reconstitute the urine, the SRM composition could be significantly altered. For example, volatilization of mercury by the cells (see reviews 2, 3) or binding of mercury to the cells [36] could alter concentrations and homogeneity of distribution of mercury. To date we have not found the microflora of the NBS house distilled water capable of volatilizing elemental mercury $\left(\mathrm{Hg}^{\circ}\right)$ from urine certified for mercury. Microorganisms present in University of Maryland disti11ed water, however, volatilized $\mathrm{Hg}^{\circ}$. After three days $0.43 \mathrm{ng} \mathrm{Hg}^{\circ}$ per $\mathrm{mL}$ was found in the headspace of the container rehydrated with nonsterile water. A sterile control showed no volatilization of mercury. No other volatile mercury containing metabolites (table 1) were detected. The possibility exists that microorganisms in other distilled water systems can also volatilize mercury.

Table 3. Numbers of viable microorganisms in freeze-dried urine (SRMs 2671 and 2672 ) reconsitiuted with NBS distilled water. Storage was at $1{ }^{\circ} \mathrm{C}$ or $22{ }^{\circ} \mathrm{C}$. Numbers are organisms per $\mathrm{mL}$.

\section{Time of storage $\left(1{ }^{\circ} \mathrm{C}\right)$}

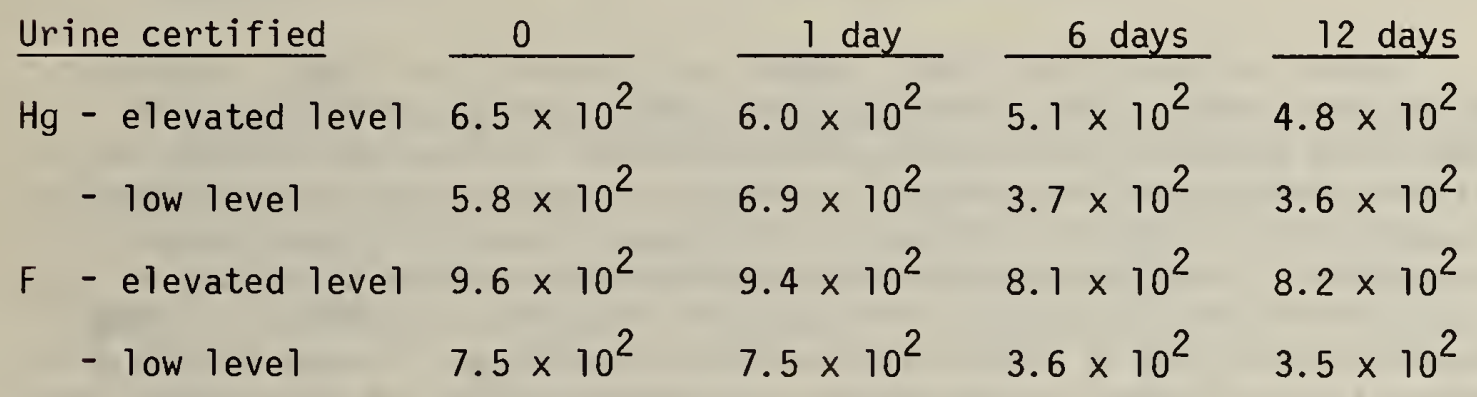

Time of storage $\left(22^{\circ} \mathrm{C}\right)$

$\begin{array}{lcccc}\text { Hg - elevated level } & 0 & \frac{1 \text { day }}{6 \text { days }} \\ \text { - low level } & - & & 4.3 \times 10^{2} & >10^{8} \\ \text { F - elevated level } & - & & 6.5 \times 10^{2} & >10^{8} \\ - \text { low level } & - & 1.02 \times 10^{2} & >10^{8}\end{array}$


Microorganisms which grew in the mercury-certified urine SRM bound a significant percentage of the mercury. After six days 21.4 to 24.2 percent of the mercury was bound to cells (cells were removed from solution by filtration) in the low level mercury in urine SRM, representating a concentration factor of 1514 to 3300 by the microorganisms, which generally formed a sediment in the bottom of the container (table 4). Cells occurring in other distilled water systems could have a higher or lower binding affinity for mercury which could influence how quickly significant alterations in SRM composition may occur.

Table 4. Binding of mercury to cells growing in urine certified for mercury (low level)--SRM 2672. Values listed are means of duplicate runs. Bottles 1 and 2 were rehydrated with NBS distilled water, bottle 3 with University of Maryland distilled water.

\begin{tabular}{|c|c|c|c|}
\hline Bottle & $(\underline{\mathrm{Hg} \text { bound }})$ & $\frac{\mathrm{Hg} \text { bound }}{(\%)}$ & $\frac{\text { Concentration }}{\text { Factor }}$ \\
\hline 1 & 67.16 & 24.2 & 1774 \\
\hline 2 & 59.39 & 21.4 & 1514 \\
\hline 3 & 101.88 & 22.9 & 3300 \\
\hline
\end{tabular}

River sediment (SRM 1645), urban particulate (SRM 1648), brewers yeast (SRM 1569), orchard leaves (SRM 1571), and oyster tissue (SRM 1566) were examined over a range of humidities for susceptibility to attack by airborne contaminants. Visual and microscopic examination showed severe fungal deterioration of brewers yeast, orchard leaves, and oyster tissue after exposure to outdoor air for short periods of time on successive days $(3.5 \mathrm{hr}$ total) followed by incubation at room temperature and 90 or 100 percent relative humidity. Fungal growth on oyster tissue stored at 70 percent relative humidity was also noted. Plate counts of these high-humidity exposed materials were not possible due to tremendous fungal growth which literally consumed the SRMs. Plate counts were possible only with urban particulate. Data (table 5) indicate that storage at elevated relative humidity (90 to 100 percent) induces growth of microorganisms in this SRM, however at lower humidities cell numbers are no greater than those observed for previously unopened urban particulate (tables 2 and 5). Other SRMs exposed to outdoor air then stored loosely capped at ambient laboratory relative humidity (average 49 percent, range 33 to 73 percent) did not show development of microbial populations visually, microscopically or by plate counting after six months of storage. 
Table 5. Growth of microorganisms in SRMs exposed to outdoor air then stored at varying relative humidity for six months.

SRM

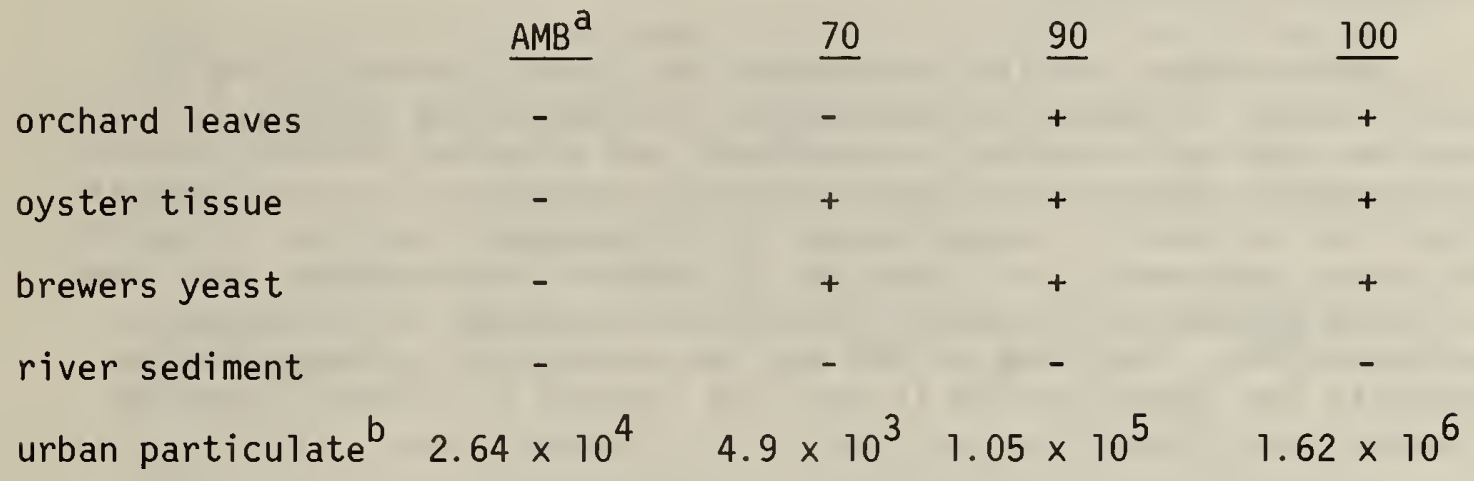

$(-)$ Values indicate no colonies on plates.

$(+)$ Values indicate dense growth on plates (severe biodeterioration).

a Range 33 to 73 percent, mean $=49$ percent, NBS general purpose laboratories

b Urban particulate contains microorganisms initially, however, counts after storage at ambient and 70 percent relative humidity were either the same or lower than previously unopened bottles (see table 2). Values listed are numbers of viable microorganisms per $\mathrm{g}$.

Although exposure to outdoor air and incubation at elevated humidities probably represent "worst" case conditions in SRM handling it was necessary to quickly identify conditions leading to SRM biodeterioration in this preliminary survey. Microorganisms present in outdoor air can be taken inside by ventilation systems or open windows. Elevated laboratory humidities may occur during warm, humid weather (especially with the advent of the energy crisis and resultant higher thermostat settings) or as a result of steam or hot water use (autoclaving, glassware washing) even in laboratories which are served by controlled humidity ventilation systems. Future studies to measure SRM water activity after different exposure times at various humidities will be instructive in determining biodeterioration potential.

No volatile chromium production has been detected from contaminated brewers yeast or orchard leaves. These studies are continuing and will be expanded to cover additional elements and SRMs listed in table 1.

4. Conclusions and Recommendations

Improper storage of certain NBS Standard Reference Materials will result in severe microbiological deterioration. The relative humidity 
of storage and contamination by outside microorganisms are the two most critical factors in deterioration of many of the SRMs examined. Urban particulate is already laden with microorganisms which will grow at elevated relative humidity. Rehydration of freeze dried urine will result in contamination and microbial growth unless the urine is rehydrated aseptically.

Under proper handling procedures set forth in most of the SRM certificates, microbial deterioration of SRMs should not occur. Exposure to airborne microbial contaminants and elevated humidity either deliberately (during weighing or removal from bottle) or accidentally (not closing the lid) could result in SRM biodeterioration. Microbial cultures, obtained by air sampling in several laboratories, have been isolated and are being tested for ability to cause deterioration of selected SRMs. How long an SRM must be exposed to a given relative humidity for deterioration is also the subject of current investigations.

At present, however, we can recommend certain certificate modifications. For example, freeze dried urine (SRM 2671 and 2672) should be rehydrated with sterile, mercury-free water. If sterile water is not available, the rehydrated SRM must be refrigerated immediately and should be used promptly. We recommend that rehydrated urine be discarded after $24 \mathrm{hr}$ [37], to ensure microbial contaminants will not grow to any extent in the SRM.

Studies designed to examine certified element composition changes due to biodeterioration in other on the shelf and proposed SRMs (table 1) are underway. These and other results will be the subject of subsequent reports.

This work was sponsored by the office of Standard Reference Materials, National Bureau of Standards. We thank Michelle Leff for technical assistance.

Certain commercial equipment, instruments, and materials are identified in this paper in order to adequately specify the experimental procedure. Such identification does not imply recommendation or endorsement by the National Bureau of Standards, nor does it imply that these items are necessarily the best available for the purpose. 


\section{REFERENCES}

1. Christian, J. H. B., Reduced Water Activity (chapter 4), in Microbial Ecology of Foods, Volume 1, Factors Affecting Life and Death of Microorganisms, Academic Press, New York (1980).

2. Iverson, W. P., and Brinckman, F. E., Microbial Metabolism of Heavy Metals (chapter 8), in Mitche11, R. (ed.), Water Pollution Microbiology, John Wiley and Sons, New York (1978).

3. Summers, A. 0., and Silver, S., Microbial Transformations of Metals, Ann Rev. Microbiol. 32, 637 (1978).

4. Johnson, D. L., Bacterial Reduction of Arsenate in Sea Water, Nature 240, 44 (1972).

5. Cox, D. P., and Alexander, M., Production of Trimethylarsine Gas from Various Arsenic Compounds by Three Sewage Fungi, Bul1.

Environ. Contam. Toxicol. 9, 84 (1973).

6. Holm, T. R., Anderson, M. A., Stanforth, R. R., and Iverson, D. G., The Influence of Adsorption on the Rates of Microbial Degradation of Arseric Species in Sediments, Limnol. Oceanogr. 25, 23 (1980).

7. McBride, B. C., and Wolfe, R. S., Biosynthesis of Dimethylarsine by Methanobacterium. Biochemistry 10, 4312 (1971).

8. Magos, L., Tuffery, A. A., and Clarkson, T. W., Volatilization of Mercury by Bacteria, Brit. J. Industr. Med. 21, 294 (1964).

9. Stary, J., Havlik, B., Kratzev, K., Prasilova, J., and Hanusova, J., Mercury Circulation in Aquatic Environment. Part 3: Mercury Transformations in Sediments, Acta Hydrochim. Hydrobiol. $\underline{8}, 29$ (1969).

10. Jensen, S., and Jernelov, A., Biological Methylation of Mercury in Aquatic Organisms, Nature 223, 753 (1969).

11. Berdicevsky, I., Shoyerman, H., and Yannai, S., Formation of Methylmercury in the Marine Sediment under in vitro Conditions, Environ. Res. 20, 325 (1979).

12. 01 son, B. H., and Cooper, R. C., In situ Methylation of Mercury in Estuarine Sediment, Nature 252, 682 (1974).

13. Edwards, T., and McBride, B. C., Biosynthesis and Degradation of Methylmercury in Human Faeces, Nature 253, 462 (1975).

14. Havlik, B., Stary, J., Prasilova, J., Kratzer, K., and Hanusova, J., Mercury Circulation in Aquatic Environment. Part 2: Metabolism of Methyl and Pheny 1 Mercury in Phytoplankton, Acta. Hydrochim. Hydrobiol. ㄱ, 401 (1979). 
15. Akagi, H., Mortimer, D. C., and Miller, D. R., Mercury Methylation and Partition in Aquatic Systems, Bul1. Environ. Contam. Toxicol. 23, 372 (1979).

16. Lebedeva, E. V., and Lyalikova, N. N., Reduction of Crocoite by Pseudomonas chromatophila sp. nov., Microbiology 48, 405 (1979).

17. Bopp, L. H., Ehrlich, H. L. , Friello, D. A., and Chakrabarty, A. M., Plasmid Coded Chromate Resistance in a Hudson River Isolate, Abstracts of the Annual Meeting of the Am. Soc. Microbiol., p. 138 (1979).

18. Banwart, W. L., and Bremner, J. M., Formation of Volatile Sulfur Compounds by Microbial Decomposition of Sulfur-Containing Amino Acids in Soils, Soil Biol. Biochem. 7,359 (1975).

19. Banwart, W. L., and Bremner, J. M., Identification of Sulfur Gases Evolved from Animal Manures, J. Environ. Qual. 4, 363 (1975).

20. Aneja, V. P., Overton, J. H., Cupitt, L. T., Durham, J. L., and Wilson, W. E., Carbon Disulfide and Carbonyl Sulfide from Biogenic Sources and their Contributions to the Global Sulfur Cycle, Nature 282, 493 (1979).

21. Zinder, S. H., and Brock, T. D., Microbial Transformations of Sulfur in the Environment (chapter 10), in Nriagu, J. 0. ed., Sulfur in the Environment. Part II: Ecological Impacts, John Wiley and Sons, New York (1978).

22. Reamer, D. C., and Zoller, W. H., Selenium Biomethylation Products from Soil and Sewage Sludge, Science 208, 500 (1980).

23. Chau, Y. K., Wong, P. T. S., Silverberg, B. A., Luxon, P. L., and Bengert, G. A., Methylation of Selenium in the Aquatic Environment, Science 192, 1130 (1976).

24. Harrison, R. M., and Laxen, D. P. H., Natural Source of Tetraalkyllead in Air, Nature 275, 738 (1978).

25. Wong, P. T. S., Chau, Y. K., and Luxon, P. L., Methylation of Lead in the Environment, Nature 253, 263 (1975).

26. Jackson, J. A., Blair, W. R., Brinckman, F. E., and Iverson, W. P., Gas Chromatographic Speciation of Methylstannanes in the Chesapeake Bay Using Purge and Trap Sampling with a Tin-Selective Detector, submitted for publication.

27. Braman, R. S. and Tompkins, M. A., Separation and Determination of Nanogram Amounts of Inorganic Tin and Methyltin Compounds in the Environment, Ana1. Chem. 51, 12 (1979). 
28. Hodge, V. F., Seidel, S. L., and Goldberg, E. D., Determination of Tin(IV) and Organotin Compounds in Natural Waters, Coastal Sediments, and Macro Algae by Atomic Absorption Spectrophotometry, Anal. Chem. 51, 1256 (1979).

29. Rodina, A. G., Methods in Aquatic Microbiology, University Park Press, Baltimore, MD (1972).

30. Ferrer, E. B., Stapert, E. M., and Sokolski, W. T., A Medium for Improved Recovery of Bacteria from Water, Can. J. Microbiol. 9 , 420 (1963).

31. U. S. Environmental Protection Agency, Methods for Chemical Analysis of Water and Wastes, EPA-625-/6-74-003, Washington, DC (1974).

32. Blair, W., Iverson, W. P., and Brinckman, F. E., Application of a Gas Chromatograph--Atomic Absorption Detection System to a Survey of Mercury Transformations by Chesapeake Bay Microorganisms, Chemosphere. 4, 167 (1974).

33. Brinckman, F. E., Iverson, W. P., and Blair, W., Approaches to the Study of Microbial Transformations of Metals, in Sharply, J. M., and Kaplan, A. M. (eds.), Proc. 3rd Internat. Biodegradation Symp. Applied Science Publishers, London (1976).

34. Dean, J. A., Lange's Handbook of Chemistry, 12th ed., McGraw-Hi11, New York (1979).

35. Ehrlich, H. L., Geomicrobiology, Marcel Dekker, New York (1981).

36. Nichols, D. H., Mercury Binding to a Yeast, J. Gen. Microbiol. 30 , 429 (1973).

37. Britt, E. M., Needham, G. M., Balows, A., and Truant, J. P., Processing of Specimens and the Initiation of Primary Cultures and Smears (chapter 4), in Blair, J. E., Lennette, E. H., and Truant, J. P. (eds.), Manual of Clinical Microbiology, American Society for Microbiology, Bethesda, MD (1970). 
NBS.114A IREV. 2-8C1

U.S. DEPY. OF COMM.

BIBLIOGRAPHIC DATA

SHEET (See instructions)

4. TITLE AND SUBTITLE
1. PUBLICATION OR REPORT NO.

NBSIR 81-2246
2. Performinz Organ. Report Nof 3. Publication Date

April 1981

\section{BIODETERIORATION OF STANDARD REFERENCE MATERIALS}

5. AUTHOR(S)

G. J. 01 son, W. P. Iverson, F. E. Brinckman

6. PERFORMING ORGANIZATION (If joint or other than NBS, see instructions)

7. ContracVGrant No.

NATIONAL BUREAU OF STANDARDS

DEPARTMENT OF COMI!MERCE

8. Type of Report \& Period Covered

WASHINGTON, D.C. 20234

9. SPONSORING ORGANIZATION NAME AND COMPLETE ADDKESS (Street, City, State, ZIP)

Office of Standard Reference Materials

National Bureau of Standards

Department of Commerce

Washington, D. C. 20234

10. SUPPLEMENTARY NOTES

[] Document describes a computer program; SF-185, FIPS Software Summary, is attached.

11. ABSTRACT (A 200-worj or less foctual summary of most significant information. If document includes a significant tibliography or ititerature survey. mention it here)

Several National Bureau of Standards Standard Reference Materials have been examined for susceptibility to biodeterioration. Several of these materials were attacked by bacteria and fungi when stored at ei evated humidity after exposurc to outdoor air. Some SRMs underwent deterioration after following certificate instructions for hardling. Suggestions for some certificate revisions are made.

12. KEY WORDS (Six to twelve entries; alphabetical order: capitalize only proper names; and separate key words by semicolons) bacteria; biodeterioration; biotransformations; deterioration of materials; elentent volatilization; fungi; metals; microorganisms; Stardard Reference Materials.

13. AVAIIABILITY

ixx Unilimited

For Official Distribution. Do Nut Releise: ro NTIS

T- Order Fiom Superintenden: of Documents, U.S. Covernment Printing Office, Washington, D.C. 20402.
14. NO. OF

PRINTED PAGES

\section{8 .}

15. Price 

